\title{
Narrative Criminology as Critical Criminology
}

\author{
This is a postprint version, cite this article as: \\ Presser, Lois and Sveinung Sandberg (2019): Narrative Criminology as Critical Criminology. \\ Critical Criminology. Published online: https://doi.org/10.1007/s10612-019-09437-9
}

\begin{abstract}
Narrative criminology is a theoretical paradigm rooted in a view of stories as influencing harmful actions and arrangements. Narrative criminologists explore the storied bases of a variety of harms and also consider the narratives with which actors resist patterns of harm. We submit that narrative criminology is an apt and powerful framework for research in critical criminology because narrative criminology is fundamentally concerned with harm or resistance to harm; underscores collective involvement in the genesis of harm; illuminates the dynamism of harm and therefore the possibilities of resistance; and compels a reflexive stance on one's research. Stories are recounted at multiple levels of social life. They are self-consciously and habitually generated, structured and creative, populated by things said and things not said. The complexities of stories are a good match for the complexities of harm, crime, and justice in late modernity-core concerns of critical criminology.
\end{abstract}

Keywords: critical criminology, harm, identity, narrative criminology, reflexivity 


\section{$\underline{\text { Introduction }}$}

Narrative criminology is a theoretical paradigm centered on the view that stories influence human actions and arrangements, including those that do harm. Narratives, used synonymously with stories in this article, are temporal accounts of events that give meaning to those events. We know ourselves and others in the world in large part through stories: they inform and animate us and thus guide our actions. Narrative criminologists study the types, textual composition and mechanics of stories that influence - either promote or curb-harm-doing. We submit that narrative criminology is an apt and powerful framework for research in critical criminology.

Critical criminology is a broad term for perspectives that question, among other things: statist codifications of crime; racist, classist and gender-oppressive policies; neglect of political economy (inequality) as a cause of crime; and criminological inquiry for its own sake rather than for the sake of furthering justice (see MacLean and Milovanovic 1997). Critical criminologists are deeply concerned with power relations. They observe that what is called crime and how the criminal justice system responds to those who commit it reflect and perpetuate social inequalities. They furthermore note that criminology is apt to legitimize inequalities if it does not adopt an activist position.

In this article, we sketch narrative criminology and the state of the field - that is, theory as well as research to date - in order to build the argument that narrative criminology has critical potential inasmuch as it (1) is foundationally concerned with harm and not just illegal action; (2) underscores collective involvement in patterns of harm; (3) illuminates the dynamism of harm and therefore the possibilities for resistance; and (4) compels researcher reflexivity. Critical criminologists need not attend to narratives, but narratives surely drive the phenomena they study.

\section{Narrative Criminology: Theory and Research to Date}

Presser coined the expression and outlined the field of narrative criminology in 2009. She noticed that criminology had yet to take "the narrative turn" that related disciplines-mainly cultural studies, history, psychology, and sociology—had (Presser 2009, 2016). Whereas criminological research owes a great deal to stories (see Bennett 1981), it has rarely been about 
stories. Rather, it has largely used stories to explore other (e.g., criminogenic) factors. Until recently criminologists have not approached narrative itself as factoring into action.

However, the view of narrative as spurring action is common in studies of mass harm from fields other than criminology. For example, Mason (2002) (from English, American, and gender studies) identifies narratives that spur violent attacks on abortion clinics by representing "some particular people as pro-life warriors and others as conspiratorial enemies of life" (p. 191). Kay (2005), a philosopher, distinguishes the collective story that sustains the death penalty in the United States: "The story says it is morally permissible to harm criminals for a variety of reasons" (p. 17). Smith (2005), a cultural sociologist, theorizes war in terms of the choice of narrative genre that nations make to describe geopolitical conflicts. Analyzing three international conflicts in post-World War II United States history, he found that use of the apocalyptic narrative genre was more likely to culminate in warfare than were other genres such as tragedy. Sternberg (2003), a psychologist, and Vetlesen (2005), a philosopher, advance general theories of mass atrocities based on stories. In each of these cases, the author demonstrates that narratives shape harm perpetrated by aggregated elites.

Narrative criminology has theoretical forebears within criminology as well. Narratives are related to neutralizations, identities, and situational interpretations (Athens 1997; Becker 1963; Sykes and Matza 1957; Lemert 1967; Messerschmidt 1997). Each of these constructs is something that actors borrow from their (sub)culture to construct the world and themselves, with the result being some sort of transgression. Narrative is a more holistic rendering of actors in the world, however (Maruna and Copes 2005; Presser 2009). It is furthermore discursive, or bound to language, whereas studies of neutralizations, identities, and situational interpretations do not generally share that emphasis. Attuned to lives, the meaning of lives, and to language or meaning's actual rendering, narrative criminology invites attention to more systemic and socially organized harm-doing. Henry and Milovanovic's (1996) constitutive criminology, which posits that crime is "not so much caused as discursively constructed" (p. 170), anticipated narrative criminology. Narrative criminology concretizes the discursive focus of constitutive criminology, asking among other things which particular (narrative) discourses construct crime and how.

Some readers will connect narrative criminology with critical ethnographies by criminologists and sociologists, invaluable works that share stories told by subordinated persons (e.g., Baca 2001; Bourgeois 2003; Duneier 1999; Shukla 2016). Narrative criminology is 
distinguishable from that tradition in three ways. First, whereas many of those ethnographies, in the event, seek to point out the falsehood of dominating myths, narrative criminology scrutinizes the social production of all stories. In other words, it considers the concept of the people's "own" stories as problematic. Narrative criminologists recognize that narrators draw on a culturally delimited set of options for telling stories, and that their stories are also always influenced by interlocutors, real and imagined. Second, narrative criminologists observe that stories act in the world with both good and bad consequences. Our stories, especially when shared with others, can help us escape hardship and oppression, but they can also keep us down: witness disadvantaged supporters of right-wing leaders coming together around a particular narrative of victimization. Third, and most importantly, narrative criminology takes stories to be social forces in their own right, rather than merely stores of information about social forces. The story, and not the factual information it provides, is the phenomenon of interest. Thus, narrative criminology differs from research that assembles storylines or trajectories of events in people's lives (e.g., Agnew 2006). Because narrative criminology is primarily attentive to people's stories and not the events purportedly behind stories, the accuracy of stories is not a main concern. "True" or "untrue," stories have consequences: they affect thought and action. Thus too, unlike critical criminological approaches that tend to eschew positivism, narrative criminology sets the stage for the making of causal claims. Accordingly, narrative criminology invites both qualitative and quantitative inquiries.

Our edited volume, Narrative Criminology: Understanding Stories of Crime (Presser and Sandberg 2015), sets forth the narrative criminological approach theoretically and through application to specific empirical cases. In that volume Keeton reveals the impact of religious narratives on Indian removal policies and related atrocities in nineteenth-century America. Sandberg and Tutenges, comparing contemporary stories of addiction and bad trips with ancient folk-tales argue that even tragic drug stories can motivate drug use. O'Connor clarifies in a finegrained way the discursive devices that drug users and maximum security prisoners use to change their storylines and their lives. Tognato describes shifting public stories of tax evasion in Italy. Other chapters, such as those by Ugelvik, Fleetwood, Miller and colleagues, and Victor and Waldram, deconstruct the stories with which ex-offenders reestablish dignity and agency as members of a vilified and/or incapacitated subpopulation. Aspden and Hayward describe points of connection and disagreement between cultural and narrative criminology. Aspden's memoir 
centering on his youthful attempt at robbery helps flesh out synergies between the sensual and the narrative: "The story I told myself was that I had fallen to the bottom, that I was exiled from my community and peers" (p. 250).

In a special 2016 issue on narrative criminology in Crime, Media, Culture, the editors, Sandberg and Ugelvik, and Presser in a separate contribution, recount the history of the perspective. One of the signal accomplishments of that publication is the dialogue it convenes among cutting-edge criminologies that focus on culture. For example, Katz draws connections between his cultural criminological approach and narrative criminology in the context of the Rodney King riots. Katz (2016) writes: "Culture in crime refers to the understandings employed by people as they commit crimes. These include folk narratives of how crimes occur, which are used by offenders to organize the social interaction required to commit crimes" (p. 233). Carrabine, and collaborators Copes and Ragland connect images to stories and thus visual criminology to narrative criminology.

Narrative criminology also occasions cross-disciplinary dialogue. A body of work by psychologists Youngs, Canter and their colleagues (see Youngs and Canter 2012; Ioannou et al. 2015 , 2017) directs analytic attention to particular roles that a person assumes in committing a crime. Although based in psychology, this research follows narrative criminology's fundamental de-centering of criminal propensity, as narrative roles and not person-types align with offending. The psychological branch of the narrative criminology tree has implications for humane practice, such as in helping addicts achieve lasting recovery (Kougiali et al. 2017).

In very recent years scholars doing narrative criminology have engaged with literary arts. Colvin (2015), a literary and language scholar, considers the productive use of literature in prisons (see also Wilson 2014). Brisman (2017) argues for scholarly attention to fiction given its consequences for real-world environmental harm. A deeply "storied" environmental harm is climate change, which, according to Craig (2016), will devastate us and the environment if we do not intercede in the main narrative "told" by modern American law and policy—-that of "Humans as Controlling Engineers." This narrative credits humans with "the considerable ability to control and modulate human impact on ecological systems" (Craig 2016, p. 363). Instead, Craig sees hope for outliving climate change in the form of an alternative narrative- one of climate change as trickster. "Among other things, trickster tales teach humans to expect the unexpected and that change — good or bad—is just part of life" (Craig 2016, p. 384). Trickster stories are not 
generally seen or heard in mainstream Anglo American society, and Craig connects the marginalization of indigenous cultural forms with the promise of re-writing dominant environmental law, stories, and our history.

Contemporary research in narrative criminology spans the globe and an array of storytellers and contexts. Gilmer (2017) probes piracy narratives in Somalia, while Barrera (2017) scrutinizes the drug war stories of Philippine President Rodrigo Duterte. Saarikkomäki (2016) examines youths' stories about meetings with security guards and the police in Finland, and Dollinger (2018) investigates how young criminal defendants in Germany position themselves in relation to reigning public discourses on offenders. Boonzaier (forthcoming) hones an intersectional feminist approach in analyzing the narratives of violence shared by sex workers in South Africa.

Perhaps most importantly for our argument concerning narrative criminology's critical potential is that recent studies in narrative criminology, including ones previously discussed, study up. Some explore the ways in which stories inform and sustain criminal justice, including policing, prosecution, imprisonment, and rehabilitation, and immigration control practices (e.g., Petintseva forthcoming; Tørnquist 2017; Ugelvik 2016; Wright 2016; Yardley et al. 2015). Kurtz and Upton (2017) tell us that police officer narratives, such as that of the occupying soldier, shape and are shaped by the racialized and masculinist institution of policing. Fiander and colleagues (2015) analyze the narratives of critical penal history museums in Canada and find potential for humanizing prisoners and problematizing their confinement. Some studies, such as those that discern stories of ordinary Muslims opposing Islamist terrorism (Joosse et al. 2015; Sandberg et al. 2018; Andersen and Sandberg forthcoming), take an implicit stance against violence, including state violence. This body of work has critical potential in that narrative resistance challenges the physically and discursively violent attacks, on cells and individuals associated with terrorism, narrowly referred to as "counterterrorism."

A hallmark of studies in narrative criminology is their emphasis on the complexities of stories and storytelling. Fleetwood (2014) stresses the importance of examining how narratives are embedded within socioeconomic and gender structures. Presser (2012) and Sandberg (2013), in analyses of the narratives of domestic terrorists in the United States and Norway respectively, highlight the incoherences, including contradictions, with which narrators make meaning. They also showcase the narratives' rootedness in larger and wide-ranging discourses. Sandberg, 
Tutenges and Copes (2015) take note of the plurivocality of stories of violence. In a recent piece, Sandberg and Tutenges (2018) argue that narrative play is evident in humorous stories. As suggested above and notwithstanding its topical and analytic openness, we believe that narrative criminology summons critical thinking in four related ways.

\section{Narrative Criminology's Critical Potential}

Narrative criminologists hold the view that the world is fashioned out of stories. Human beings know themselves and 'others' as characters of stories. They know temporal and specifically causal relationships as developments in plots. And those of us who study social phenomena inevitably are 'characterized': we matter to those plots. Narrative criminologists, trained on the storied nature of existence, are well positioned to recognize criminology - which is to say, ourselves - as telling stories. We also view oppression and other harm as based on stories, though not only stories. These are the conceptual bases of narrative criminology's critical and transformative potential.

\section{Focus on Harm Over Law-Breaking}

Critical criminologists question mainstream criminology's focus on law-breaking, viewing government-defined crime as an ideologically wrought designation that does not necessarily capture activities that cause harm, and occludes attention to ones that do (Kramer 1985; Michalowski 1985; Schwendinger and Schwendinger 1970). Corporate and state actions and arrangements immeasurably destructive of ecological, nonhuman, and human health and wellbeing are beyond the reach of state designations and regulations. The criminal justice system itself causes tremendous suffering that is legal, or if illegal then largely permitted, and bolsters extant injustices through selective criminalization and enforcement.

Foundational writings in narrative criminology identify harm as the object of concern. Presser and Sandberg (2015), for instance, define the field: "Narrative criminology is any inquiry based on the view of stories as instigating, sustaining, or effecting desistance from, harmful action" (p. 1). Why this focus on harm? First, narrative criminologists were from the start influenced by analyses of (not-necessarily-criminal) mass harm (Presser 2013). Second, and to 
this day, narrative criminologists are confronted frequently with the evidence that criminalization/criminal justice/punishment is itself storied - that is, constituted by stories (see for example Ugelvik 2016; Kurtz and Upton 2017).

Powerful, socially integrated individuals and institutions tell stories - and have superior capacities and opportunities to disseminate these stories. Thus, powerful and aggregate offenders are no problem for the narrative criminological perspective, unlike other theories of offending centered on economic deprivation, weak social bonds, disorganized communities, or impaired biological or psychological make-up. As seen above, exemplars of narrative criminology include research on the actions of governments and other elites.

In addition, narrative criminology is highly compatible with a view of harm as patterned and rooted in institutions, rather than as so many isolated incidents, which is the distorting tendency of mainstream criminology. Stories become hardened; they form narrative habitus, or internalized "dispositions towards particular discourses and narrative forms" which inform particular "interpretations and representations" (Fleetwood 2016, p. 182; see also Sandberg and Fleetwood 2017). "People's habitus of expected plot completions is nothing less than their sense of life's possibilities" (Frank 2010, p. 54). Institutions circulate stories to account for their practices and thereby play a key role in constructing the narrative habitus of individual actors within their purview.

\section{Collective Participation in Patterns of Harm}

Mainstream criminology concerns itself primarily with interpersonal injury, channeling "the underpinning logic of capitalist societies (which) serves to prioritise interpersonal harms over organizational and structural harms" (S. Pemberton 2016, p. 8). Critical criminologists challenge that tendency. They urge attention to the organizational and the structural.

Narrative criminology counters the individualism of the dominant approaches to the etiology of criminal behavior. Undoubtedly, narrative criminology can and does explain individual behavior - and our studies may yield very personal and idiosyncratic story featuresbut those operating within its frame know that narrative is always collectively sourced. Stories are patterned after collective forms, with standard plotlines and stock characters. Consider the tragedy and the romance, the heroic underdog and the devious foe. Stories contain and make 
reference other, collective stories, and import understandings of the latter into the present rendering. They are interdiscursive (Fairclough 2013).

Collective myths ground harmful patterns. Hochschild (2016) relates the "deep story" of American conservatism according to which the American Dream story is false for whites: they cannot really get ahead because of the privileges bestowed upon others, namely racial minorities and immigrants. Like Hogan (2006), narrative criminologists study the stories that harm's passive bystanders tell themselves. Even narrative criminologists who study individual life stories take stock of broad forms of which the life stories are derivative. Maruna (2001) notes the inspirations for desisters' redemption narratives in 12-step programs. Presser (2013) finds collective stories that both license harm-doing and avow powerlessness in the face of harmful projects one engages in or supports. She observes that institutions including industry and law are sources for those stories.

Vetlesen (2005) suggests that narrative is uniquely relevant to organized harm-doing. In contrast to "individual evil," to which he attributes individual reasons, Vetlesen (2005) explains that "[t]he collective action at work in collective evil typically identifies the victims by ideological (symbolic, narrative) means, concentrating on what they have done or are about to do against $u s "$ (p. 172; emphasis in original). Individual action likewise rests on narratives. "Individuals become the autobiographical narratives by which they tell about their lives" (Riessman 1993, p. 2) and those autobiographical narratives are no less ideologically structured than are collective narratives.

\section{Showcasing Dynamic Oppression and Possibilities of Resistance}

Oppression operates through ideology. "[T] he way in which...subaltern classes live their world will be typically shaped and influence by the dominant ideologies” (Eagleton 1991, p. 101). Stories are one highly impactful form for ideological communication (Presser 2018). Some stories are proscribed; others are simply marginalized, ignored by dominant ideologies. Prohibitions concerning whose story can be heard are means of control (Butler 1983; Colvin 2017; Sharpe 2016). Struggle necessarily involves countering dominant stories. To that end, narrative criminologists have studied resistance to harm, including resistance to stigma (Ugelvik 2015; Stone 2016; Sandberg 2008) and resistance to carceral knowledge (Berger 2015). A rich vocabulary exists for narratives that seek authority and narratives that resist-including 
narratives versus counternarratives (Joosse et al. 2015; Maan 2015), hegemonic versus subversive narratives (Ewick and Silbey 1995), and cultural versus collective narratives (Richardson 1990). We expect the recent development of narrative victimology to generate new concepts and insights (A. Pemberton, Aarte and Mulder 2018; A. Pemberton, Mulder and Aarte 2018; Walklate et al. 2018).

Narrative researchers have exposed the structures that govern storytelling and support existing social hierarchies. Molotch and Boden (1985), for example, observe: "Demands for 'just the facts', the simple answers, the forced-choice response, preclude the 'whole story' that contains another's truth” (p. 285; see also Ewick and Silbey 1995). Polletta (2006, p. 187) explains:

Certain discursive forms seem less credible or authoritative when used by certain groups. Certain discursive forms are open to all groups but are restricted to particular settings and occasions. The boundaries that institutions enforce between one discursive form and another may operate to legitimate the institution — and to insulate it from attack. In these and other ways, the conventions of culture's practical use may operate to reproduce the current state of things. By the same token, however, challenging those conventions may have transformative political effect.

Polletta's research has lessons for how subordinated groups can tell more stories in such a way as to promote their cause. For instance: "Where legal theorists have emphasized stories' capacity to elicit an easy identification with the story's narrator/protagonist, I argued that effective narratives may juxtapose discordant ideas and emotions in a way that initially prevents an easy identification, forcing the reader instead to discover the sense of an unfamiliar connection" ( $p$. 112).

If critical criminology is to help summon better worlds, it must envision structures that are at least somewhat mutable. A narrative framework offers radical potential — and hope — for as Gubrium and Holstein (2000) put it: "If we make visible the constructive fluidity and malleability of social forms, we also reveal a potential for change" (p. 503). This eye towards how the world is socially constructed through stories, and therefore can be changed by stories, is narrative criminology's most important critical potential. It is also closely connected researcher's reflexivity, another important feature of narrative criminology. 


\section{Compelling Reflexivity}

Dispelling the notion of interpretive neutrality is a signal coup of critical scholarship. Narrative criminology centers a critique of neutrality, for there can be no question that stories are always collectively created and, as such, that stories are products of specific social contexts and interests. Reflexivity is called for. That is to say, narrative criminology compels researchers to locate themselves in the story and to clarify their role within it.

The narrative criminologist gathering stories from interviews confronts her influence quite readily. If she is attentive and honest, she will notice that the supposed reasons for storytelling and the actual or intended or imagined audience - including her position - shape the telling. Stories are told for - or tailored to - particular audiences, with the interviewer being one such audience (Cicourel 1964; Presser 2005; Mishler 1986; Holstein and Gubrium 2000). The interview is "another context that we must take into consideration in trying to answer the question of what the story is about" (Mishler 1986, p. 247). But even those stories obtained from archival or media sources presuppose choices about what "the story" is and where "the story" begins and ends. Across data sources but perhaps especially through ethnography, scholars aggregate reported stories to arrive at a single story. In each of these cases, the analyst has created "the story" as much as the original communicators have.

In short, analysts do not occupy a space outside of the realm of meaning-making: they can make no claim to detachment. Auto-ethnographic narrative criminological research, where the researcher is her/himself a storyteller, takes the reflexive charge to its logical conclusion (e.g., Aspden and Hayward 2015; Presser and Taylor 2011). Other studies pursue participants' stories but make clear the researcher's role in it (see Petintseva forthcoming; Presser 2004). The reflexive stance in regard to narrative work can be depressing, as when Presser and Taylor (2011) saw themselves channeling big, pervasive stories that support harm to nonhuman animals. It can unsettle our academic socialization: it did for Sandberg (2010), who found himself redirecting an interviewee's story about good reasons for murder. If narrative criminologists believe that stories influence action, and that interviews are a site for the co-production of narratives, it is necessary to reflect on the kinds of stories we participate in constructing, willingly or unwillingly cultivating. 
Fortunately, the reflexive stance can also prefigure a method for achieving social change, as when Pentineseva (forthcoming) deploys a data collection method she calls 'light Socratic dialogue' to unsettle stories, told in interviews, that enable official mistreatment of migrant youth. Following critical criminology, many narrative criminologists have also taken their studies outside the "academic box," with the aim of effecting societal reflexivity and positive social change. One example is a new project sponsored by the University of Oslo, "MuslimVoices." In short video clips accessible on several social media platforms (Facebook, Youtube, Instagram) young Muslims challenge public stereotypes, presenting an effective counter-narrative to widespread negative stories of Islam and Muslims.

\section{$\underline{\text { Conclusions and Future Directions }}$}

Narrative criminology follows other disciplines in its understanding of narrative as penetrating social life. Its key premise is that narratives impact human action. Narrative criminologists explore the storied bases of a variety of harms and consider the narratives with which actors resist patterns of harm. We have therefore argued that narrative criminology can be a useful framework for critical criminology. Critical criminologists have paid invaluable attention to the depth and breadth of harm-doing-historical roots in intersectional inequalities, global expanse in world systems, grounding in state-corporate collaborations, and so forth. Narrative criminologists ask how these and other phenomena are rendered as meaningful events unfolding over time, and register the impact of those (storied) meanings.

Contemporary harms are complex, involving multiple, often geographically dispersed parties who may or may not collaborate mindfully and/or as coalitions. They may nevertheless share a story or operate on compatible stories. Hence the present-day significance of narrative criminology. First, the populism that has taken hold around the world may be seen as the product of a basic narrative — on which a congeries of national and regional stories converge — of being historically put-upon and cheated by immigrants of color, Jews, Muslims, progressives, government, and so on. Politicians, online propagandists, and angry young men are among the agents whose complementary narratives produce the ills of this phenomenon. Second, narrative criminologists are writing from and about Asia, Africa, and Latin America, as well as Europe and North America. We need still more narrative criminology from outside the Western context, 
and more from refugee camps, sacrifice zones, and war zones; the paradigm of narrative criminology is ripe for inquiries in those spaces, by analysts who can enlighten us to canonical forms and (narrative) forms of resistance.

We would note here some challenges. Narrative is a wily construct and an ambitious one - more than is widely recognized - for analysts. For example, the story that influences actors is almost certainly not the one that observers are in a position to "collect." Stories do not stay the same from the time of action to the time of post-action reflection. Narrative criminology insists that stories somehow precede actions, even though stories are told following action. Narrative criminologists must lay bare this sort of intellectual leap. In fact, though, where patterned, persistent harms are concerned - the kind to which critical criminologists are most attentive - the enabling stories keep getting told. The challenge of capturing the story at time zero is therefore attenuated. Other challenges, such as determining what "the" story is, are addressed through reflexivity and candor.

Important future directions for a critical narrative criminology include how narratives are conveyed visually, how narratives arouse us emotionally, and how narratives are disseminated and sometimes achieve dominance. A critical narrative criminological perspective would emphasize these hegemonic narratives. In these times of rising xenophobia, issues of dominating constructions of 'race' and religion come to mind. Arguably, narrative studies have some limits when it comes to studying ideological hegemony. The most important narratives are often taken for granted (Sandberg 2016). Some stories are recounted self-consciously and creatively, while we channel others with little or no awareness. Stories themselves contain absences. As such, narrative criminology cannot limit itself to the text of narratives, but must also include ways to understand what is 'not said' in narratives (Presser forthcoming). Narrative criminologists should not only analyze stories, but also try to reconstruct them critically — in a way that resists domination and promotes social justice. 


\section{$\underline{\text { References }}$}

Agnew, Robert. 2006. "Storylines as a Neglected Cause of Crime." Journal of Research in Crime and Delinquency 43(2): 119-147.

Andersen, Jan C. and Sveinung Sandberg. (Forthcoming). "Countering Violent Extremism. Everyday Narrative Resistance Among Young Muslims in Norway." Emerald Handbook of Research in Narrative Criminology, edited by Jennifer Fleetwood, Lois Presser, Sveinung Sandberg, and Thomas Ugelvik. Bingley, UK: Emerald Publishing.

Aspden, Kester, and Keith J. Hayward. 2015. "Narrative Criminology and Cultural Criminology: Shared Biographies, Different Lives? Chapter 9 (pp. 235-259) in Narrative Criminology: Understanding Stories of Crime, edited by Lois Presser and Sveinung Sandberg. New York and London: New York University Press.

Athens, Lonnie. 1997. Violent Criminal Acts and Actors Revisited. Urbana, IL: University of Illinois Press.

Aydin, Cemil. 2017. The Idea of the Muslim World: A Global Intellectual History. Cambridge, MA: Harvard University Press.

Baca, Jimmy Santiago. 2001. Foreword (ix-xii). in Evans, Jeff (ed.). 2001. Undoing Time: American Prisoners in Their Own Words. Boston: Northeastern University Press.

Bamberg, Michael, and Alexandra Georgakopoulou. 2008. "Small Stories as a New Perspective in Narrative and Identity Analysis.” Text \& Talk 28(3): 377-396.

Barrera, Dan Jerome. 2017. "Drug War Stories and the Philippine President.” Asian Journal of Criminology 12(4): 341-359.

Becker, Howard S. 1963. Outsiders: Studies in the Sociology of Deviance. New York: Free Press. 
Bennett, James. 1981. Oral History and Delinquency: The Rhetoric of Criminology. Chicago: The University of Chicago Press.

Berger, Nichlas Permin. 2015. "The Creative Use of the ADHD Diagnosis in Probationers' Self-Narratives." Journal of Scandinavian Studies in Criminology and Crime Prevention 16(1): 122-139.

Boonzaier, Floretta. (Forthcoming). "Studying Marginality: Doing Intersectional, Feminist Narrative Analysis." Emerald Handbook of Research in Narrative Criminology, edited by Jennifer Fleetwood, Lois Presser, Sveinung Sandberg, and Thomas Ugelvik. Bingley, UK: Emerald.

Bourgois, Philippe. 2003. In Search of Respect, $2^{\text {nd }}$ edition. Cambridge: Cambridge University Press.

Box, Steven. 1983. Power, Crime, and Mystification. New York: Tavistock.

Brisman, Avi. 2017. "On Narrative and Green Cultural Criminology." International Journal for Crime, Justice and Social Democracy 6(2): 64-77.

Butler, Judith. 2004. Precarious Life: The Powers of Mourning and Violence. London: Verso.

Carrabine, Eamonn. 2016. "Picture This: Criminology, Image and Narrative." Crime, Media, Culture 12(2): 253-270.

Cicourel, Aaron Victor. 1964. Method and Measurement in Sociology. New York: The Free Press of Glencoe. 
Colvin, Sarah. 2017. "Unerhört? Prisoner Narratives as Unlistened-to Stories (and Some Reflections on the Picaresque)." Modern Language Review 112(2): 440-458.

Colvin, Sarah. 2015. "Why Should Criminology Care About Literary Fiction? Literature, Life Narratives and Telling Untellable Stories.” Punishment \& Society 17(2): 211-229.

Copes, Heith, Andy Hochstetler, and Sveinung Sandberg. 2015. "Using a Narrative Framework to Understand the Relationship Between Drugs and Crime. Criminal Justice Review 40(1): $32-46$.

Copes, Heith, and Jared Ragland. 2016. "Considering the Implicit Meanings in Photographs." Crime, Media, Culture 12(2): 271.

Craig, Robin Kundis. 2016. "Learning to Live With the Trickster: Narrating Climate Change and the Value of Resilience Thinking." Pace Environmental Law Review 33(3): 351-396.

Davis, Joseph E. 2002. "Narrative and Social Movements: The Power of Stories." Pp. 3-29 (Chapter 1) in Stories of Change: Narrative and Social Movements, edited by Joseph E. Davis. Albany, NY: State University of New York Press.

DeKeseredy, Walter S. 2011. Contemporary Critical Criminology. London: Routledge.

Dollinger, Bernd. 2018. "Subjects in Criminality Discourse: On the Narrative Positioning of Young Defendants.” Punishment \& Society 20(4): 477-497.

Douglas, Mary. 1986. How Institutions Think. Syracuse, NY: Syracuse University Press.

Duneier, Mitchell. 1999. Sidewalk. New York: Farrar, Straus and Giroux.

Eagleton, Terry. 1991. Ideology: An Introduction. London: Verso. 
Ewick, Patricia, and Susan S. Silbey. 1995. "Subversive Stories and Hegemonic Tales: Toward a Sociology of Narrative." Law \& Society Review 29(2): 197-226.

Fairclough, Norman. 2013. Critical Discourse Analysis: The Critical Study of Language, $2^{\text {nd }}$ edition. Abingdon, Oxon, UK: Routledge.

Ferrell, Jeff. 2007. "For a Ruthless Cultural Criticism of Everything Existing." Crime, Media, Culture 3(1): 91-100.

Fiander, Sarah, Ashley Chen, Justin Piché, and Kevin Walby. 2016. "Critical Punishment Memorialization in Canada." Critical Criminology 24(1): 1-18.

Fleetwood, Jennifer. 2016. "Narrative Habitus: Thinking Through Structure/Agency in the Narratives of Offenders." Crime, Media, Culture 12(2): 173-192.

Fleetwood, Jennifer. 2014. Drug Mules: Women in the International Cocaine Trade. London: Palgrave McMillan.

Fleetwood, Jennifer, and Sveinung Sandberg (Forthcoming): Narrative Criminology and Ethnography. Oxford Handbook of Ethnographies of Crime and Criminal Justice, edited by Sandra M. Bucerius, Kevin D. Haggerty and Luca Berardi. Oxford: Oxford University Press.

Frank, Arthur W. 2010. Letting Stories Breathe: A Socio-Narratology. Chicago and London: The University of Chicago Press.

Gilmer, Brittany. 2017. "Hedonists and Husbands: Piracy Narratives, Gender Demands, and Local Political Economic Realities in Somalia.” Third World Quarterly 38(6): 1366-1380 
Gubrium, Jaber F., and James A. Holstein. 2000. “Analyzing Interpretive Practice.” Pp. 487508 (Chapter 18) in Norman K. Denzin and Yvonna Lincoln (eds.) Handbook of Qualitative Research. Thousand Oaks, CA: Sage.

Hasday, Jill Elaine. 2000. "Contest and Consent: A Legal History of Marital Rape.” California Law Review 88: 1373-1505.

Henry, Stuart, and Dragon Milovanovic. 1996. Constitutive Criminology: Beyond Postmodernism. Thousand Oaks, CA: Sage.

Hochschild, Arlie. 2016. Strangers in Their Own Land: Anger and Mourning on the American Right. New York: The New Press.

Hogan, Patrick Colm. 2006. "Narrative Universals, Nationalism, and Sacrificial Terror: From Nosferatu to Nazism.” Film Studies 8(1): 93-105.

Holstein, James A., and Jaber F. Gubrium. 2000. The Self We Live By: Narrative Identity in a Postmodern World. New York: Oxford University Press.

Ioannou, Maria, David V. Canter, Donna E. Youngs, and John Synnott. 2015. "Offenders' Crime Narratives Across Different Types of Crimes." Journal of Forensic Psychology Practice 15(5): 383-400.

Ioannou, Maria, David V. Canter, and Donna E. Youngs. 2017. "Criminal Narrative Experience: Relating Emotions to Offence Narrative Roles During Crime Commission." International Journal of Offender Therapy and Comparative Criminology 61(14): 15311553.

Joosse, Paul, Sandra Bucerius, and Sara K. Thompson. 2015. "Narratives and Counternarratives: Somali-Canadians on Recruitment as Foreign Fighters to al Shabaab.” British Journal of Criminology 55(4): 811-832. 
Katz, Jack. 2016. "Culture Within and Culture About Crime: The Case of the 'Rodney King Riots'." Crime, Media, Culture 12(2): 233-251.

Kay, Judith W. 2005. Murdering Myths: The Story Behind the Death Penalty. Lanham, MD: Rowman and Littlefield.

Keeton, Robert M. 2015. “The Race of Pale Men Should Increase and Multiply': Religious Narratives and Indian Removal.” Chapter 5 (pp. 125-149) in Narrative Criminology: Understanding Stories of Crime, edited by Lois Presser and Sveinung Sandberg. New York and London: New York University Press.

Kougiali, Zetta, Alessandra Fasulo, Adrian Needs, and Darren Van Laar. 2017. "Planting the Seeds of Change: Directionality in the Narrative Construction of Recovery From Addiction." Psychology \& Health 32(6): 639-664.

Kurtz, Don L., and Lindsey Upton. 2017. "War Stories and Occupying Soldiers: A Narrative Approach to Understanding Police Culture and Community Conflict." Critical Criminology 25(4): 539-558.

Lemert, Edwin M. 1967. Human Deviance, Social Problems, and Social Control. New York: Prentice-Hall.

Maan, Ajit. 2015. Counter-Terrorism: Narrative Strategies. Lanham, MD: University Press of America.

MacLean, Brian D., and Dragan Milovanovic. 1997. "Thinking Critically About Criminology." Pp. 11-16 (Chapter 1) in Thinking Critically About Crime. Vancouver: Collective Press.

Maruna, Shadd. 2001. Making Good: How Ex-Convicts Reform and Rebuild Their Lives. Washington, DC: American Psychological Association. 
Maruna, Shadd and Heith Copes. 2005. "Excuses, Excuses: What Have We Learned From Five Decades of Neutralization Research." Crime and Justice: A Review of Research 32: 221320.

Messerschmidt, James W. 1997. Crime as Structured Action: Gender, Race, Class, and Crime in the Making. Thousand Oaks, CA: Sage.

Mishler, Elliot G. 1986. "The Analysis of Interview-Narratives.” Pp. 233-255 (Chapter 12) in Theodore R. Sarbin (ed.), Narrative Psychology: The Storied Nature of Human Conduct. New York: Praeger.

Molotch, Harvey L., and Deirdre Boden. 1985. "Talking Social Structure: Discourse, Domination and the Watergate Hearings.” American Sociological Review 50 (3):273-288.

O’Connor, Patricia. 2015. "Telling Moments: Narrative Hot Spots in Accounts of Criminal Acts.” Chapter 7 (pp. 174-203) in Narrative Criminology: Understanding Stories of Crime, ed. Lois Presser and Sveinung Sandberg. New York and London: New York University Press.

Pemberton, Simon. 2016. Harmful Societies: Understanding Social Harm. Bristol, UK: Policy Press.

Pemberton, Antony, Pauline G.M. Aarte, and Eva Mulder. 2018. "Stories as Property: Narrative Ownership as a Key Concept in Victims' Experiences With Criminal Justice.” Criminology and Criminal Justice. Published online before print: https://doi.org/10.1177/1748895818778320

Pemberton, Antony, Eva Mulder, and Pauline G.M. Aarten. 2018. "Stories of Injustice: Towards a Narrative Victimology." European Journal of Criminology. Published online before print: https://doi.org/10.1177/1477370818770843 
Petintseva, Olga. (Forthcoming). “Confessions After 'Socrates Light': Eliciting and Countering Narratives of Youth Justice Officials." Emerald Handbook of Research in Narrative Criminology, edited by Jennifer Fleetwood, Lois Presser, Sveinung Sandberg, and Thomas Ugelvik. Bingley, UK: Emerald.

Polletta, Francesca. 2006. It Was Like a Fever: Storytelling in Protest and Politics. Chicago and London: The University of Chicago Press.

Presser, Lois. (Forthcoming). "The Story of Antisociality: Determining What Goes Unsaid in Dominant and Dominating Narratives." Emerald Handbook of Research in Narrative Criminology, edited by Jennifer Fleetwood, Lois Presser, Sveinung Sandberg, and Thomas Ugelvik. Bingley, UK: Emerald.

Presser, Lois. 2018. Inside Story: How Narratives Drive Mass Harm. Berkeley and Los Angeles, CA: University of California Press.

Presser, Lois. 2016. "Criminology and the Narrative Turn.” Crime, Media, Culture 12(2): 137151.

Presser, Lois. 2013. Why We Harm. New Brunswick, NJ and London: Rutgers University Press.

Presser, Lois. 2012. "Getting On Top Through Mass Murder: Narrative, Metaphor, and Violence." Crime, Media, Culture 8(1): 3-21.

Presser, Lois. 2009. “The Narratives of Offenders.” Theoretical Criminology 13(2): 177-200.

Presser, Lois. 2006. “'I'll Come Back and Stalk You': Contradictions of Advocacy and Research For Women Criminologists.” Women \& Criminal Justice 17(4): 19-36. 
Presser, Lois. 2004. "Violent Offenders, Moral Selves: Constructing Identities and Accounts in the Research Interview." Social Problems 51(1): 82-101.

Presser, Lois and Sveinung Sandberg. 2015. "Research Strategies for Narrative Criminology. J. Miller and W. Palacios (Ed.) Advances in Criminological Theory: The Value of Qualitative Research for Advancing Criminological Theory. Abingdon, Oxon and New York: Routledge.

Presser, Lois, and Sveinung Sandberg. 2015. "Introduction: What is the Story?" Pp. 1-20 in Narrative Criminology: Understanding Stories of Crime, edited by Lois Presser and Sveinung Sandberg. New York and London: New York University Press.

Presser, Lois, and William V. Taylor. 2011. "An Auto-Ethnography of Hunting." Crime, Law and Social Change 55(5): 483-494.

Reiman, Jeffrey. 2001. The Rich Get Richer and the Poor Get Prison: Ideology, Class, and Criminal Justice, $6^{\text {th }}$ edition. Boston: Allyn and Bacon.

Riessman, Catherine Kohler. 1993. Narrative Analysis. Newbury Park, CA: Sage.

Saarikkomäki, Elsa. 2016. "Perceptions of Procedural Justice Among Young People: Narratives of Fair Treatment in Young People's Stories of Police and Security Guard Interventions. British Journal of Criminology 56: 1253-1271.

Sandberg, Sveinung. 2013. "Are Self-Narratives Unified or Fragmented, Strategic or Determined? Reading the Manifesto of A. B. Breivik in Light of Narrative Criminology." Acta Sociologica 56(1): 65-79.

Sandberg, Sveinung. 2010. "What Can 'Lies' Tell Us About Life? Notes Towards a Framework of Narrative Criminology." Journal of Criminal Justice Education 21(4): 447-465. 
Sandberg, Sveinung. 2009. “A Narrative Search for Respect.” Deviant Behavior 30(6): 487- 510.

Sandberg, Sveinung, Jan Andersen, Jan Christoffer; Tiffany Linn Utvær Gasser, Marius Linge, Idil Abdi Abdulle Mohamed, Samah Shokr, and Sébastien Tutenges. 2018. Unge Muslimske Stemmer: Om Tro og Ekstremisme. [Young Muslim Voices: On Faith and Extremism]. Oslo: Oslo University Press.

Sandberg, Sveinung and Sébastien Tutenges. 2018. "Laughter in Stories of Crime and Tragedy: The Importance of Humor for Marginalized Populations." Social Problems. Published online before print. doi: $\underline{10.1093 / \text { socpro/spy019 }}$

Sandberg, Sveinung and Jennifer Fleetwood. 2017. "Street Talk and Bourdieusian Criminology: Bringing Narrative to Field Theory." Criminology \& Criminal Justice. 17(4): 365-381.

Sandberg, Sveinung, Atte Oksanen, Berntzen, Lars Erik, and Tomi Kiilakoski. 2014. "Stories in Action: Cultural Influences of School Shootings on the Terrorist Attacks in Norway." Critical Studies on Terrorism 7(2): 277-296.

Sandberg, Sveinung, and Sébastien Tutenges. 2015. "Meeting the Djinn: Stories of Drug Use, Bad Trips, and Addiction." Chapter 6 (pp. 150-173) in Narrative Criminology: Understanding Stories of Crime, edited by Presser, Lois and Sveinung Sandberg. New York and London: New York University Press.

Sandberg, Sveinung, Sébastien Tutenges, and Heith Copes. 2015. "Stories of Violence: A Narrative Criminological Study of Ambiguity.” British Journal of Criminology 55: 11681186.

Sandberg, Sveinung, and Thomas Ugelvik. 2016. "The Past, Present, and Future of Narrative Criminology: A Review and an Invitation." Crime, Media, Culture 12(2): 129-136. 
Scott, Marvin B., and Stanford M. Lyman. 1968. "Accounts.” American Sociological Review $33(1): 46-62$.

Sharpe, Christina. 2016. In the Wake: On Blackness and Being. Durham, NC: Duke University Press.

Shukla, Rashi, K. 2016. Methamphetamine: A Love Story. Oakland, CA: University of California Press.

Smith, Philip. 2005. Why War? The Cultural Logic of Iraq, the Gulf War, and Suez. Chicago: University of Chicago Press.

Sternberg, Robert J. 2003. "A Duplex Theory of Hate: Development and Application to Terrorism, Massacres, and Genocide.” Review of General Psychology 7(3): 299-328.

Stone, Rebecca. 2016. "Desistance and Identity Repair: Redemption Narratives as Resistance to Stigma." British Journal of Criminology 56(5): 956-975.

Sykes, Gresham M., and David Matza. 1957. "Techniques of Neutralization: A Theory of Delinquency." American Sociological Review 22: 664-673.

Törnqvist, Nina. 2017. Att Göra Rätt: En Studie om Professionell Respektabilitet, Emotioner och Narrativa Linjer Bland Relationsvåldsspecialiserade Åklagare. [Doing Just Right: A Study on Professional Respectability, Emotions and Narrative Lines Among Prosecutors Specialized in Relationship Violence]. Stockholm University, Faculty of Social Sciences, Department of Criminology Ph.D. thesis.

Ugelvik, Thomas. 2016. "Techniques of Legitimation: The Narrative Construction of Legitimacy Among Immigration Detention Officers." Crime Media Culture 12(2): 215-232. 
Ugelvik, Thomas. 2015. "The Rapist and the Proper Criminal: The Exclusion of Immoral Others as Narrative Work on the Self." Chapter 1 (pp. 23-41) in Narrative Criminology: Understanding Stories of Crime, edited by Presser, Lois and Sveinung Sandberg. New York and London: New York University Press.

Vetlesen, Arne Johan. 2005. Evil and Human Agency: Understanding Collective Evildoing. Cambridge, UK: Cambridge University Press.

Yardley, Elizabeth, David Wilson, Diane Kemp, and Michael Brookes. 2015. "Narrative Beyond Prison Gates: Contradiction, Complexity, and Reconciliation.” International Journal of Offender Therapy and Comparative Criminology 59(2): 159-179.

Youngs, Donna and David V. Canter. 2012. "Narrative Roles in Criminal Action: An Integrative Framework for Differentiating Offenders.” Legal and Criminological Psychology 17(2): 233-249.

Walklate, Sandra, JaneMaree Maher, Jude McCulloch, Kate Fitz-Gibbon, and Kara Beavis. 2018. "Victim Stories and Victim Policy: Is There a Case for a Narrative Victimology?" Crime, Media, Culture. Published online before print: https://doi.org/10.1177/1741659018760105

Wilson, Jeffrey R. 2014. "Shakespeare and Criminology." Crime, Media, Culture 10 (2): $97-$ 114.

Wright, Sarah. 2016. “'Ah ... the Power of Mothers': Bereaved Mothers as Victim-Heroes in Media Enacted Crusades for Justice." Crime, Media, Culture 12(3): 327-343. 